\title{
Development of Education during the Years 1944 - 1948 in Albania
}

\author{
Dr. Bedri Kola \\ Professor at the Albanian University \\ Head Department of Education \\ bedrikola@yahoo.com
}

\section{Doi:10.5901/mjss.2014.v5n4p423}

\begin{abstract}
Upon taking power in late 1944, the communist regime gave high priority to reopening the schools and organizing the whole education system to reflect communist ideology. The regime's objectives for the new school system were to wipe out illiteracy in the country as soon as possible, to struggle against "bourgeois survivals" in the country's culture, to transmit to Albanian youth the ideas and principles of communism as interpreted by the party, and finally to educate the children of all social classes on the basis of these principles. The 1946 communist constitution made it clear that the regime intended to bring all children under the control of the state. All schools were soon placed under state management. At the same time, due to the lack of specialists in many fields of knowledge, a lot of young people were sent abroad to the countries Albania had diplomatic connections with (Soviet Union, Czechoslovakia, Poland, Romania etc.)
\end{abstract}

Keywords: Education, communist regime, historical truth, principles of socialism.

\section{Introduction}

Albania was liberated in 1944. The Communist Party that led the Fascist War, undertook several reforms to establish "dictatorship of the proletariat" and the elimination of political opponents. As a result of this internal war, cultural heritage, especially education and Albanian schools were hardly damaged.

One of the key events, which was the core development of education in the years 1944-1948, called the first stage of development of socialist school, is the 1946 Education Reform.

Educational reform goals were:

1. Class transformation, school, regarding the scope and content.

2. Transformation of the views on the involvement of children of the working masses and the masses themselves, and therefore the creation of an education-owned by masses.

To achieve these objectives began propaganda against the cultural heritage and especially the Albanian schools using slogans and quotes extracts from V.I.Lenini. "Essence of the class society and as a result that of classes segregation education, Lenin wrote, it is the right of the rich to receive equal education....... School class accepts only city dwellers and requires from all students only one thing: to pay themselves for their education. "

A real school for the people and a mass education, Enver Hoxha wrote, can be established only in the socialist society, where after the disappearance of private property, the objectives of the society law developments are identical to the interests and desires of the proletariat and all the working masses, whose leadership is the Communist Party.

The work to achieve the second objective focused on the establishment of compulsory primary education, the creation of a unique national, secular education system for all the Albanian people.

It is important to highlight the fact that the struggle for the democratization of education took place during 19121939 , i.e. after the declaration of independence. This was deepened particularly during 1920-1924, where educational congresses were organized and some key successes were achieved on the national, secular and state education developments in primary compulsory education. These important changes were further developed and improved during the regime of King Zog in the years 1924-1939.

These democratic changes with national character and secularization of the school were fully established and set in place during the years 1933-1934, by the Education Minister at the time Mr.Mirash Ivanaj. The so called 'Ivanaj education reform' during the academic year 1933-1934 put an end to 85 private schools operating in Albania and allowed only the secular schools to continue operation in private basis. The Minister requested the Albanian Parliament to change and amendment the Articles 206 and 207 in the Albanian State Statutes, which allowed the opening of foreign schools. 
"Education of Albanian citizens, is an exclusive right of the Albanian State. Provided only in the state schools, in different education levels, according to the laws. "

"Primary education for all Albanian citizens is compulsory and free of charge." In 1933-1934 school year, for the first time in the history of Albania, there were only state operating schools opened. Apart from the nationalization of schools, the Minister Ivanaj focused his work as well in its secularization.

But while these developments were key to the success of education, mirroring democratic struggle and enriched with laws on education in years 1924-1939, after liberation in 1944, these remained mere demagogic laws, and interpreted as copies of Western bourgeois laws that were never implemented. In addition, they were quite limited. In Albania there was no pre-primary education, with the exception of Tirana city. Higher education, afternoon schools for the workers and secondary education was almost a privilege and primary education was restricted to the villages. Schools were not evenly spread nationwide, there were differences between the village and city schools as well as between high schools. There were differences in the development of education in different regions and amongst education for boys and girls.

Illiteracy was wide spread in Albania, $80 \%$ of the population was illiterate and 90\% of women do not know to write and read.

In addition to severe economic and educational backwardness, devastating damages were caused during the Second World War in the country. As a result Albanians were facing a harsh winters with no electricity, primitive and destroyed agriculture, paralyzed economy, without shelter and food.

These conditions of course affected the education system. During the war schools were burned and destroyed and a good part of them were closed for one to three years. Many students and teachers left teaching and went to war and became partisans.

After the war, the devastating damages in the school buildings and educational materials were enormous. There were vast numbers of 7 to 10 year old children who had never been to school. Academic documentation that was destroyed led to anomalies associated with the students' school continuation. In all reports of district education departments of the school year 1944-1945 clearly show such a poor state of the schools.

During the Fascist War the education development gained a new popular approach, the school had new elements such as:

- Fully state owned.

- Compulsory Primary Education.

- Equality between boys and girls.

- Eradication of illiteracy.

But after the country's liberation, work focused on the democratization of education. Educational developments took place alongside political, economic and social transformations.

On May 5, 1945, Enver Hoxha, noted in his speech: "The present democratic government will be interested in youth education, more then a parent who is concerned about the education of his children .... This education will be for all and especially for the children of the long-suffering and hard working people, so that they can use the education and science knowledge's they receive in serving the nation. "

This kind of State politics deepened in a number of decisions and laws and was consolidated with Education Reform in August 1946.

During the years 1945-48 several economic, democratic and socialist transformations took place, for e.g.:

- Agrarian reform, large and medium land owners were overrun and the land was given to landless peasants and poor farmers with hardly any land.

- The creation of the socialist sector of the economy, thus began the nationalization of industry and foreign capital in Albania.

- The creation of the socialist sector in agriculture, agricultural farms were established and the first agricultural cooperatives. These measures led to the year 1948 when the general industrial production was two times greater than that of agricultural production in 1938 and way over the pre-war production.

Consequently the economic situation was improving, and this influenced the progress of education, resulted to its spread country wide and the increase in school gradual and steady attendance.

\section{Efforts to Achieve Universal Compulsory Primary Education}

Compulsory primary education started with the order of Government dated 09.13.1913 in the city of Vlora, nr.249, 
published in the Official Journal of the government. "It calls for compulsory primary education to all students in Albania". Later on during the Sulejman Delvina governments, Lushnje Educational Conference of 1920, and the Conferences held in Tirana in the years 1922 and 1924, have paid close attention in taking measures for the implementation of compulsory primary education.

These measures increased during the Reign in the years 1928 to 1939. The education law of 1934, Article 46 states: "Compulsory school is fully implemented in a country where the Ministry of Education can certify that school buildings and staff are enough to care for all school age students."

The law assigns the local government to build new schools, provide maintenance tools and equip the schools with educational materials. As a result in 1938-1939 school year there were 643 schools in Albania, however compulsory education failed to cater all children aged 7 to 14 years.

After liberation, compulsory education was one of the main and important tasks of the Communist Party. Based on the strengths, which rose out of the democratic framework with assigned tasks of creating a new communist state with socialist features. During the years 1945-48 compulsory primary education was not achieved $100 \%$ even though there was a lot of work done for its implementation; it was only reached in year 1952.

Compulsory primary education could be fully implemented only when the schools were state owned. This was sanctioned by law in the People's Republic of Albania Constitution in 1946. "In order to raise the level of education of the people, the state provides education for ALL people able to attend schools and other educational institutions. Especially, the government takes care of the children's education in the state schools. There can't be private schools except by law decided otherwise. "

Communist state did not allow the opening of private schools. In April 1945 the nationalization of primary schools was completed. In Tirana infant schools ran by the Stigmantine Sisters were closed down as well as the Italian elementary school. In Shkodra private primary schools by Franciscan Saveriane Stigmantine were all closed down including several other schools and kindergartens.

After the end of the academic year 1944-1945, as press reports confirm, district education departments requested the implementation of an education reform immediately after the liberation. Therefore, a new law was needed more adaptable to the new national education in the communist state. A technical committee of the Ministry of Education in April 1945 started drafting and adopting the 1934 education law. Although technically the committee was supposed to use education lance in reality this law changed to accommodate the socialist ideas and remove the power of the old regime. The chapter on taxes, on compulsory primary education and on competencies of several executive education committees (education sections prefectures), was removed entirely.

These changes provided opportunities for local governments to participate in the development of education; this was later extended to 7-year primary education system which was established in 1945-1946. During the same years the Ministry of Education began preparations to enforce the compulsory education law while considering the new school structures and materials needed to respond to the needs of the pupils. The new law required that in the places with an existing functioning school the compulsory education law to be reinforced. This education law did oblige the schools to enroll not only the age group required in the classrooms but to include drop out-children or children who were never enrolled due to War. "The problem of education is very broad and important, Enver Hoxha emphasized at the fifth plenum CPA, as we made a great revolution in the field of social and economic developments, the education should move with the same pace."

Consequently, the Council of Ministers for Education Reform Commission was established in April 1946.

The draft law on compulsory education for primary aged children from 7 years to 10 years old who were not enrolled at the time. The Law emphasized the obligation of parents to send their children to school, to track attendance and laid out the actions to be taken otherwise. The Law did oblige the school principal and the local education government authorities to implement the compulsory primary education.

The new law on education there were some changes as well in the structure and content. So the first article stated that education in Albania was structured throughout the country in primary schools, 7 years schools and high schools.

In article 2 of the education structure the new elementary school, which was 5 years during the first two years after liberation would be changed into 4 years.

Establishment of the same type of school in the city and countryside, as well as the reduction of primary school year created the opportunity for the unification of the school system and easier for pupils to complete school. The first four year of compulsory education created a strong ground for the transition into the 7-year extension of education and later to higher education.

The following table shows how the number of primary schools and kindergartens has increased in the years 1944-48 


\begin{tabular}{|c|c|c|c|c|}
\hline Educational Institution & $\begin{array}{c}\text { School year } \\
1944-45\end{array}$ & $\begin{array}{c}\text { School year } \\
1945-46\end{array}$ & $\begin{array}{c}\text { School year } \\
1946-47\end{array}$ & $\begin{array}{c}\text { School year } \\
1947-48\end{array}$ \\
\hline Primary schools & 928 & 1097 & 1609 & 1751 \\
\hline Kindergardens & 35 & 33 & 91 & 135 \\
\hline
\end{tabular}

During the 1947-48 school year there were 1751 primary schools and 135 kindergartens in 2711 villages and towns that had our country.

Providing school buildings was carried out by people in a room home on voluntarily basis. Opening schools buildings was only one aspects but qualified teachers were needed therefore this was only a temporarily solution to the education system. State allocated funds for construction and reconstruction of new schools to meet the educational requirements. In November 1945 the Ministry of Education appointed a fund of 2,720,000 gold francs for the construction of new schools.

Consequently the state opened most of the elementary schools. After 3 years, and the successful implementation of compulsory education the construction of schools decreased. Thus in 1947-48 school year 142 new schools were established mostly in northern Albania, in districts Shkodra, Kukes and Bishop. However, the lack of instructional materials was visible in the newly established schools. There were no proper desks, furniture's, chairs, blackboards, textbooks, notebooks and even pencils were missing. The state could not afford so teachers had worked out systems of sharing and using traditional handmade tools. The consolidation began in 1948 when the new communist state, the dictatorship of the proletariat, the problem of instructional and learning materials started to be tackled.

The Council of Ministers appointed a special fund of 20 million leks to improve the basic materials for the schools and refurbishing them with furniture's. These measures led to the stabilization of the education system for the first time after the liberation of the country.

Another important task for the implementation of compulsory education were the teachers. The number of teachers before liberation was low. In the 1938-39 school year there were in total 1349 teachers in Albania. The growing number of schools required a considerable number of teachers.

In the absence of teachers and trainers, Ministry of Education accepted all those who had completed secondary education to be trained in a short period and to be assigned to schools immediately after. This was not welcomed and was highly criticized by Albanian intellectuals who proposed as a solution to stop the massive opening of school buildings with no teachers.

The press strongly criticized these intellectual views. The newspaper "Union" wrote: "Some say that in this way we raise half educated people that will do more harm than good. This is not right. We also want to educate youth in perfect schools. But we must consider the actual situation today. I do not think we raise half educated people this way. Leaving the youth out of the school system with the reason of making it better later is not the solution. "

Teacher preparation and training courses took several months along the way and followed up in-school teacher training. At first courses were organized by districts and before the school year 1945-46 the training was organized on a national scale. As a result of this work the number of teachers has increased from year to year such as:

\begin{tabular}{|c|c|c|c|c|}
\hline Teachers & Year 1944-45 & Year 1945-46 & Year 1946-47 & Year 1947-48 \\
\hline Primary school teachers & 1743 & 2069 & 2612 & 2772 \\
\hline Kindergarten teachers & 41 & 41 & 133 & 224 \\
\hline Total & 1784 & 2110 & 2745 & 2996 \\
\hline
\end{tabular}

By increasing the number of schools and teachers, the number of students continued to grow:

\begin{tabular}{|c|c|c|c|c|}
\hline Pupils & Year 1944-45 & Year 1945-46 & Year 1946-47 & Year 1947-48 \\
\hline Primary schools & 54360 & 77240 & 134524 & 151817 \\
\hline Kindergarten & 2094 & 2336 & 6313 & 10002 \\
\hline
\end{tabular}

I should emphasize that all the teachers were supposed to have the same capacity building in terms of the educational level and their professional development. However, according to a statistics of the Ministry of Education on the educational level of teachers in the 1946-47 school year were: 'From 2612 primary teachers only 93 teachers had come 
out of the pedagogical school, 108 teachers who had been taking part in several short trainings and courses, the rest of the teachers had no documents or evidence for being qualified teachers. This situation changed later on as the training program for teachers increased.

In year 1946 was the first nationally organized training of teachers to enhance the quality of teaching in schools, which would improve the teaching level of teachers without formal education. The Ministry of Education created a separate branch that dealt with the problems of teacher training. In 1946 the first course for training of secondary school teachers was opened and 68 teachers attended.

During 1947 the teacher training programs were held both nationally and district based where a large number of teachers attended. During 1948 there was an increase on the numbers of teacher participation in training courses.

The teacher training was conducted using 2 methods:

1. Seminars aimed in preparing the teacher in political and ideological way (Marxist - Leninist).

2. Methodical seminars aimed in building their methodical and professional capacity.

During this period the teachers were asked to complete their education on part time basis without interrupting their work. The Ministry of Education gave clear guidance for teachers who had not completed secondary education teachers, to finish it.

The Council of Ministers decided in 1948 that all teachers who had 15 years of work in education should complete their professional training on the job.

As a result the number of teachers teaching in the 7-year-old system, who had to carry out studies without interrupting their work, was 2500 teachers, 500 teachers from the pedagogical school and 200 teachers teaching in the pedagogical institute.

\section{Conclusions - Compulsory Education System}

The compulsory education system which was set in place encountered great difficulties in the early years.

One key factor was the fact that compulsory education was set only for children from $7-10$ years old only 7 years old who had not been enrolled in school at all. The terms of educational regulations in all districts were the same.

The Ministry of Education required regular attendance tracking, time reporting and collected evidence from the education departments in all districts. At the end of every week, each school draw up lists of missing children and send it to the education section in their districts.

Press and especially the magazine "National Education" devoted much room for The Education Reform, criticizing their mistakes and shared good experience that would contribute to improving the implementation.

In the first years after the liberation apart from the desire to be educated there were some people thinking "Why do we have to go to school", "we are and will be peasants", these thoughts were results of an educational backwardness.

Other educational difficulties were of subjective and objective character such as, lack of learning materials, bad weather in winter which prohibited children who had long distances to reach school, and sometimes the indifference of local government and district education departments. The key problem was the low level of education of the teaching staff that was reflected in the low levels of pupils' achievements.

These issues affected directly the regular attendance of the pupils in the schools. During the years of this study there were significant differences between students who were officially enrolled, those in fact that were regularly attending and the number of pupils continuing education after the compulsory years.

During the years 1947-48, which was considered the most stable school period, the government focus was the pupils' achievements. For this purpose a variety of methods were applied progressively basically aimed at increasing pupils' learning achievements. Several district study centers were created for extracurricular summer courses for children who had drop out, pupils to pupils support programs, different quizzes, etc.

For the full implementation of compulsory primary education, the Council of Ministers issued a statute law in September 1949, providing certain amendments to the 1946 education law. This status law stated that primary education was compulsory for all boys and girls ranging from ages 7 years up to the completion of primary school. Pupils were obliged to continue and complete primary education even older than 10 years, especially for those children with no proper school access.

As a result, compulsory primary education was implemented $100 \%$ in the $1951-52$ school year, after eight years of the liberation of the country. This paved the way for the implementation at a later stage of the 7-year compulsory education. 


\section{References}

Magazine "National Education", No. 15, 1963, page 16.

Beqja. Hamit, historical overview of our socialist school, Volume II, 1966, page 29.

Magazine Pedagogical no. 4, 1975, page 128.

Enver Hoxha, The foundation building of the new Albania (Memoirs), Tirana 1975, page 210.

Magazine Pedagogical,no.4, year 1975,page 128.

Institute of Pedagogical Studies, History of education and pedagogical thinking Albania, Tirana 2003, page 443

Rama Fatmira, Magazine Pedagogical, Creating a truly socialist school, Tirana 1975, page $12^{1}$ lbid.

AQSH.Fondi 195, file 19, sheet 4, 1945 "None of the schools in the prefecture Vithkuq has not been able to work, highlighted in the report of Korca".

Rama.F., Pedagogical Magazine No. 6, 1974, page 145.

E. Hoxha, act III, page 39, "Youth in war and work" May 5, 1945.

History of Albania Labour Party, pages 222-223.

Institute of Pedagogical Studies, History of education and pedagogical thinking, Albanian National Government Education in Vlore, Tirana 2003, page 421.

Official Gazette, 09.28.1934 Tirana, organic laws of Education Decree dated September 26, 1934

Official Gazette, date 19 March 1946.

AQSH.Fondi 195, file 19, sheet 4, 1945 "Verdict No.761 Council of Ministers, dated 19.12.1945.

Official Decision of the Council of Ministers, No.Prot.675/27, dated 4.04.1946.

Official Journal dated September 10, 1946, Decree no. 115, dated August 17, 1946, declared the law no.282.

Magazine "Education", Tirana, 1946, page 23.

A.Q.SH.Fondi 195, file 19, sheets 1, 1947, Order the Ministry of Education and Culture for repairing and equipping the schools date 15.07.1947.

Official Gazette, dt.14.05. 1948 Decision of the Council of Ministers to improve the educational materials conditions of schools.

The newspaper "Union", dated November 28, 1945.

AQSH.Fondi 195, File 191, page 21, 1948, Statistics of the Ministry of Education and Culture.

Pedagogical Magazine, No. 4, Tirana, 1975, page 147.

A.Q.SH.Fondi 195, File 11, page 7, December 1948, Teacher Qualification Programs.

Official Gazette dated 25.09.1948, Decision of the Council of Ministers No.226, dated 09.25.1948.

A.Q.SH. Fondi 195, File 11, page 9, December 1948, Teacher qualification Programs.

A.Q.SH.Fondi 195, File 19, page 2, December1948, Report sent to Prime Minister 04.29.1948, protocol 131/140

Official Decree - Law 730 date 5.09.1949 "On some amendments to the Law no.281, dated 17/08/1946, on compulsory primary education. 